\title{
Karakteristik Tugas Manajamen Puncak dalam Pendidikan Islam
}

\author{
Muh. Shulthon Rachmandhani \\ IAIN Ponorogo, Indonesia \\ Email: muhammadshulthonrachman@gmail.com
}

\section{Edi Irawan}

IAIN Ponorogo, Indonesia

Email:nawariide@iainponorogo.ac.id

DOI: https://doi.org/10.21154/sajiem.v2i2.58

\begin{abstract}
Top management means a group of individuals who hold the title, CEO, president, or chairman of the board. Usually in a company there are two people who occupy top management positions, one is the president, and one of them is the Chief Executive Officer (CEO). At SMP Muhammadiyah 4 Balong Ponorogo, the top management position is held by the vice principal. The duties of the vice principal are as follows: 1) Administration. 2) Islamic and Muhammadiyah fields. 3) Student Affairs. 4). Facilities and infrastructure sector. This article aims to determine the duties of the vice principal as top management in Islamic education. The method used in this research is a qualitative case study. The results showed that the top management had carried out their duties related to Islamic religious education at SMP Muhammadiyah 4 Balong Ponorogo. Duties of the Deputy Head of Division include; 1. Deputy Head of Curriculum. 2. Deputy Principal of Ismuba School. 3. Deputy Head of Student Affairs. 4. Deputy Head of Facilities and Infrastructure. Where each wakask has the characteristics of their respective duties, namely: 1. The vice principal of the curriculum in carrying out his
\end{abstract}


duties has the characteristics of an executive manager. 2. In carrying out his duties, the Deputy Principal of Ismuba has the characteristics of an educator and administrator. 3. The deputy head of student affairs in carrying out his duties is administrative in nature. 4. The Deputy Principal of the School of Facilities and Infrastructure in carrying out his duties is an executive manager.

Keywords: Top Management, Islamic Education

\section{Pendahuluan}

Pendidikan bertujuan untuk mengembangkan kemampuan dan membentuk budi pekerti luhur serta peradaban bangsa dalam rangka mencerdaskan kehidupan bangsa; Pendidikan juga bertujuan untuk mengembangkan potensi peserta didik menjadi orang yang beriman dan bertakwa kepada Tuhan Yang Maha Esa, berakhlak mulia, dan menjadi warga negara yang bertanggung jawab. Pendidikan diartikan sebagai upaya sadar yang dilakukan oleh keluarga, masyarakat, dan pemerintah melalui kegiatan bimbingan, pengajaran, atau pelatihan di sekolah dan di luar sekolah untuk seumur hidup. ${ }^{1}$ Urwick, menjelaskan bahwa pendidikan merupakan upaya untuk mengeluarkan semua potensi yang terpendam di dalam pikiran dan jiwa individu. Ini bukanlah proses terbatas yang berakhir ketika siswa telah lulus. Ini adalah proses yang harus berlangsung dari buaian sampai liang kubur. ${ }^{2}$

Islam merupakan agama yang dianut oleh sebagaian besar penduduk di Indonesia. Jika dicermati dari berbagai variasi pendidikan yang ditawarkan oleh lembaga pendidikan Islam. Tentunya dapat dibedakan mana yang merupakan lembaga pendidikan Islam, dan mana yang bukan merupakan lembaga pendidikan Islam. Salah satunya, dapat terlihat dari jenis model, dan bentuk lembaga tersebut, di mana lembaga pendidikan Islam meliputi bentuk yang paling tradisional sampai bentuk yang modern. Ibrahim Bafadhal mentipologikan lembaga ini ke dalam tiga jenis yaitu; formal, nonformal, dan informal. Lembaga pendidikan formal adalah jenis lembaga pendidikan dengan susunan dan komposisi yang lebih tertata dengan rapi, serta memiliki jenjang dari pendidikan dasar hingga pendidikan tinggi. Adapun pendidikan nonformal merupakan jenis lembaga pendidikan yang keberadaannya berada di luar pendidikan formal. Lembaga ini pun untuk sistem keorganisasiaannya juga dilakukan secara sistematis, terencana, serta terstruktur, selain itu jug

${ }^{1}$ Imron Mutaqin, "Supervision Planning at Islamic Education Institutions: Google Scholar Library Studies and Mendeley's Reference Manager," Istawa: Jurnal Pendidikan Islam 5, no. 02 (2020): 222-38.

2 Ake, "Top Management Education, An Evaluation Study.Swedish Council for Personnel Administration, Stockholm.," 1967. 
memiliki tingkatan jenjang kelas tertentu. Mayoritas layanan institusi pendidikan nonformal ini tersedia, untuk melayani mereka yang belum sempat untuk menyelesaikan sekolahnya di lembaga formal. Lembaga pendidikan informal merupakan lembaga pendidikan yang lingkupnya lebih mengarah pada keluarga dan masyarakat. ${ }^{3}$

Sekolah sebagai tempat terjadinya interaksi belajar mengajar di antara siswa dengan guru memiliki delapan standar yang harus dipenuhi. Standar tersebut diantaranya adalah standar proses, standar kompetensi lulusan, standar isi, standar pendidik dan tenaga kependidikan, standar pembiayaan, standar pengelolaan, standar penilaian, dan standar saran dan prasarana. Untuk mensukseskan seluruh kegiatan yang terjadi di sekolah. Kehadiran kepala sekolah dibutuhkan untuk memimpin, menentukan kebijakan, serta mengambil keputusan supaya dapat memajukan sekolah yang dipimpinnya. Melalui kepemimpinan yang amanah kesuksesan sekolah dapat diraih secara bersama-sama. Oleh sebab itu, kepala sekolah tidak dapat melakukan pekerjaannya sendirian,melainkan membutuhkan tenaga ahli untuk membantunya di dalam mengelola bidang-bidang tertentu yang ada di sekolah. Bidang tersebut seperti kurikulum, kesiswaaan, sarana dan prasarana, dan sebagainya sesuai dengan kebutuhan sekolah masing-masing. Posisi tersebut dapat diisi oleh guru yang diberikan tugas tambahan sebagai wakil kepala sekolah guna membantu kepala sekolah di dalam menjalankan tugasnya di sekolah. Sudah sewajarnya, apabila guru yang dipilih tersebut memiliki kemampuan manajerial yang baik di dalam menjalankan tugasnya sebagai wakil kepala sekolah.

Manajemen puncak diartikan sebagai sekelompok orang yang dinilai mempunyai kemampuan untuk menduduki posisi sebagai pucuk pimpinan di sebuah perusahaan maupun di lembaga tertentu. Mereka dapat disebut sebagai ketua, direktur, CEO, presiden. Sering kali di dalam sebuah perusahaan mempunyai dua orang yang menduduki jabatan sebagai top management. Di mana yang satu adalah presiden, dan yang lainnya adalah Chief Executive Officier (CEO). ${ }^{4}$ Wheelen menjelaskan terkait manajemen puncak adalah jabatan puncak di dalam suatu organisasi untuk dapat mendorong laju organisasi tersebut di dalam meraih tujuan yang telah ditetapkan sebelumnya, secara bersama. ${ }^{5}$ Manajemen puncak juga lebih dikenal sebagai tingkat atas/ eksekutif. Di mana tugas-tugas yang seharusnya

${ }^{3}$ Ibrahim Bafadhol, "Lembaga Pendidikan Islam Di Indoesia," Jurnal Edukasi Islami Jurnal Pendidikan Islam 06, no. 11 (2017): 72.

${ }^{4}$ Jerold B Warner, Ross L. Watts, and Karen H Wruck, "Stock Prices and Top Management Changes," Journal of Financial Economics 20, no. C (1988): 461-92, https://doi.org/10.1016/0304-405X(88)90054-2.

${ }^{5}$ C. Wheelen, T. L., Hunger, J. D., Hoffman, A. N., \& Bamford, Strategic Management and Business Policy: Globalization, Innovation and Sustainablility 14th Edition (Pearson, 2014). 
dilaksanakan oleh mereka lebih kepada pola tugas untuk menyusun dan mengatur kondisi manajerial di bawahnya. ${ }^{6}$ Alam, S menjelaskan top management, juga berfungsi untuk menentukan arah kebijakan lembaga atau organisasi yang dipimpinnya. Sehingga di dalam menjalankan tugasnya ini, idealnya bagi seorang manajer puncak memiliki kemampuan kerja sama yang baik. Sebab mereka, juga memiliki tugas untuk dapat membina, mengarahkan, menasehati, dan melakukan kerja sama secara interaksional dengan berbagai komponen yang terdapat di sebuah organisasi. ${ }^{7}$ Hall menyusun fase yang berbeda dari pengembangan manajemen puncak di sepanjang urutan waktu: Tahap 1 yang dia panggil pelatihan pascasarjana. Tahap 2 adalah periode pengalaman kerja pertama setelah penyelesaian pelatihan spesialis dasar. Tahap 3 adalah pelatihan berlanjut di kursus pengembangan perusahaan dan manajemen eksternal, keduanya umum dan khusus. Tahap 4 berkaitan dengan kursus manajemen senior. ${ }^{8}$

Beberapa definisi tentang manajemen puncak di atas, dapat disimpulkan bahwa manajemen puncak merupakan jabatan tertinggi dalam sebuah organisasi, perusahaan, maupun sebuah institusi yang pelakunya bisa disebut ketua, CEO, pimpinan tertinggi, maupun kepala yang memiliki tugas untuk mengarahkan, menasehati, sekaligus pembuat keputusan setiap kebijakan untuk dapat mencapai tujuan organisasi yang telah direncanakan secara bersama-sama. Selain itu, sebagai manajemen puncak juga memiliki tanggung jawab moral untuk terus menjaga dan merawat hubungan interaksional lingkungan organisasi yang dipimpinnya. Di mana menurut Hall, untuk setiap fase pengembangan manajemen puncak melewati beberapa fase sebagai berikut: Tahap 1 yang dia panggil pelatihan pascasarjana. Tahap 2 adalah periode pengalaman kerja pertama setelah penyelesaian pelatihan spesialis dasar. Tahap 3 adalah pelatihan berlanjut di kursus pengembangan perusahaan dan manajemen eksternal, keduanya umum dan khusus. Tahap 4 berkaitan dengan kursus manajemen senior.

Kemampuan manajerial dapat dipahami sebagai sekumpulan ideologi tentang praktik dan nilai organisasi yang digunakan untuk membawa perubahan mendasar di dalam organisasi, keuangan, dan budaya layanan publik yang diberikan, khususnya di dalam bidang pendidikan. ${ }^{9}$ Dari kasus sebelumnya, seorang manajer di sekolah telah memiliki nilai-nilai yang

\footnotetext{
${ }^{6}$ Solihin, Pengantar Manajemen (Jakarta: Erlangga, 2009).

${ }^{7}$ Ketut Sudarsana et al., Pengembangn Media Pembelajaran Berbasis Teknologi Pendidikan, Jayapanguspress.Penerbit.Org, accessed July 9, 2020, http://jayapanguspress.org.

${ }^{8}$ N.Hall, In 7th International Confferences on Bussines Management Education (Unpub Mimeogr: OECD, 1960).

${ }^{9}$ Rosemary Deem and Kevin J. Brehony, "Management as Ideology: The Case of 'new Managerialism' in Higher Education," Oxford Review of Education 31, no. 2 (June 2005): 217-35, https://doi.org/10.1080/03054980500117827.
} 
terinternalisasi, tujuan yang dibangun, pola kerja yang mencerminkan keharusan sistem manajemen perusahaan, seperti manajemen hierarkis yang kuat, kontrol anggaran, maksimalisasi pendapatan. ${ }^{10}$

Manajemen puncak ketika diterapkan di dalam dunia pendidikan. Sudah sewajarnya sebagai top management memiliki keunggulan sebagai berikut: 1) Memiliki akhlak yang mulia, yang merupakan tujuan di dalam penyelengaraan pendidikan Islam. Rasulullah telah mensabdakan "aku diutus untuk menyempurnakan aklah yang karimah. 2) Bahagia dunia akhirat merupakan tujuan utama di dalam penyelenggaraan pendidikan Islam. 3) Out put yang diharapkan adalah terbentuknya siswa mandiri, profesional dan mampu berdaya saing di dunia kerja. 4) Mendidik siswa-siswi dengan pelajaran yang terkait dengan fenomena alam supaya siswa-siswi mampu memikirkan dari setiap kejadian yang terjadi dari setiap ayat kauniyah. 5) Mengajarkan keterampilan dalam bidang lainnya kepada siswa-siswi, agar mereka siap bersaing di dalam lingkungan kerja, dan berguna dalam kehidupan bermasyarakat."

Hasil penelitian sebelumnya tentang manajemen puncak menunjukkan bahwa penerapan sistem informasi akuntansi pada koperasi sekolah memiliki keterpengaruhan yang positif terhadap kemampuan di dalam memanfaatkan teknologi informasi, keterlibatan pengguna, dukungan dari manajemen puncak, dan keahlian di dalam pemakaian sistem informasi akuntansi. ${ }^{12}$ Penelitian sebelumnya juga menunjukkan bahwa kinerja: (1) wakasek di bidang kurikulum tergolong "baik", (2) wakasek di bidang kesiswaan juga tergolong "sangat baik", (3) wakasek bidang sarana dan prasarana juga tergolong "sangat baik", dan (4) wakasek bidang humas juga berada pada kondisi kategori "baik". Hanya saja diperluka keaktifan kepala sekolah di dalam memantau melakukan evaluasi, serta meningkatkan perbaikan, dan motivasi kepada para wakasek. ${ }^{13}$

Pendidikan Islam sebagai mata pelajaran wajib yang harus diajarkan di sekolah, telah diinvestasikan dengan berbagai penggunaan dan makna dari waktu ke waktu. Dalam hal ini sebagai istilah luas yang terdiri dari kategori berikut: 1) Ajaran Islam, disediakan di masjid, organisasi, dan rumah; 2) Pendidikan Agama Islam, ditawarkan sebagai mata pelajaran di sekolah

10 Moh Slamet Untung IAIN Pekalongan, "Implementing Functions Of Management In Islamic Education Instituions," n.d.

${ }^{11}$ Dosen Pendidikan et al., "Tujuan Pendidikan Islam," Jurnal Pendidikan Islam 6, no. November (2015): 151-66, http://103.88.229.8/index.php/tadzkiyyah/article/view/1876.

12 Kadek Kusuma Pardanil and I Gst Ayu Eka Damayanthi, "Pengaruh Pemanfaatan Teknologi, Partisipasi Pemakai, Manajemen Puncak, Dan Kemampuan Pemakai Terhadap Efektivitas Sistem Informasi Akuntansi," E-Jurnal Akuntansi 19, no. 03 (2017): 2234-61.

${ }^{13}$ Arifin Suking Sulistia Paudi, Ikhfan, "Kinerja Wakil Kepala Sekolah Menengah Pertama Dilihat Dari Tugas Pokok Dan Fungsiny," Manajemen Pendidikan 02, no. 02 (2020): 192-205. 
umum; dan, 3) Pengajaran tentang Islam, mengacu pada mata kuliah nonkonfesional tentang Islam yang ditawarkan kepada mahasiswa Muslim dan non-Muslim. Pendidikan Islam boleh jadi memiliki karakteristik sebagai jenis pendidikan yang berdasarkan pada ideologi Islam yang juga merupakan keseluruhan total kebijakan pendidikan dan panduan formal, dan informal yang secara langsung berkaitan dengan keidealan Islamisasi masyarakat, dan pelatihan individu maupun kelompok supaya dapat menuju ke jalan yang benar melalui fasiltas perkembangan kedua material dan non material. Dengan kata lain pendidikan Islam tidak hanya mengajarkan tentang $\mathrm{Al}-$ Qur'an dan Hadis. Namun juga mengajarkan ilmu pengetahuan, dan sejarah umat Islam. ${ }^{14}$ Hal ini seperti yang disampaikan oleh Ibnu Khaldun bahwa kecenderungan dari penyelenggaraan pendidikan Islam untuk mencapai kemaslahatan, kebaikan, ketakwaan, serta menciptakan manusia-manusia yang dapat menghadapi segala tantangan kehidupan di dunia. Apa yang disampiakn oleh Ibnu Khaldun tersebut juga seperti yang disampaikan oleh Al-Ghazali bahwa orientasi dari pendidikan Islam adalah membentuk manusia berakhlak dan berilmu sehingga menjadikannya pribadi-pribadi yang utama. ${ }^{15}$

Dengan demikian dapat diambil sebuah benang merah tentang hakikat pendidikan Islam: 1) Al-Qur'an dan Hadist adalah sumber ajaran utama dalam pendidikan Islam. 2) penciptaan pribadi yang bernilai Islami menadi landasan bagi guru dalam penyelenggaraan pendidikan Islam yang dilakukannya. 3) tarikh, sejarah, kisah-kisah yang terdapat di dalam ajaran Islam juga menjadi pedoman dalam penyeenggaraan pendidikan Islam. Dengan kata lain prinsip pendidikan Islam di lembaga pendidikan adalah mutlak yang harus ada. ${ }^{16}$

Berdasarkan hasil penjajakan awal di lapangan, peneliti mendapatkan informasi bahwa Sri Amini, S. Ag selaku Wakil Kepala Sekolah bidang Keislaman dan Kemuhammadiyahan di SMP Muhammadiyah 4 Balong, melakukan MOU dengan lembaga Umi Foundation. Pihak sekolah juga melakukan MOU dengan pihak Pimpinan Daerah Muhammadiyah Kabupaten Ponorogo, untuk mengirimkan salah satu ustadz ataupun ustadzah untuk memberikan ceramah singkat setiap hari Jum'at pagi yang dimulai dari pukul o6.oo WIB sampai dengan pukul o6.30 WIB. ${ }^{17}$ Dari hasil wawancara tersebut

${ }^{14}$ Ali Khalid Mardawi, "Islamic Educatin Toward a Comprehensive View," King Saud University 1, no. 2 (1989): 3-14.

${ }^{15}$ Miftahur Rohman and Hairudin Hairudin, "Konsep Tujuan Pendidikan Islam Perspektif Nilai-Nilai Sosial-Kultural," Al-Tadzkiyyah: Jurnal Pendidikan Islam 9, no. 1 (2018): 21, https://doi.org/10.24042/atjpi.v9i1.2603.

${ }^{16}$ Lukis Alam, "Internalisasi Pendidikan Islam Dalam Perguruan Tinggi Di Kampus," Istawa: Jurnal Pendidikan Islam 1, no. 2 (2016): 101, https://doi.org/10.24269/ijpi.v1i2.171.

${ }^{17}$ Hasil Wawancara dengan Sri Amini, S. Ag selaku Wakasek Keislaman dan Kemuhammadiyahan di SMP Muhammadiyah 4 Balong Ponorogo, 04-01-2021 di SMP Muhammadiyah 4 Balong Ponorogo. 
dapat diketahui bahwa Wakasek Keisalaman dan Kemuhammadiyahan telah menjalankan tugasnya sebagai manajemen puncak di bidang administrasi. Tugas bidang administrasi untuk menekankan prestasi, dan di sampaikan kepada guru terkait komitmen mereka untuk memupuk prestasi akademik, menetapkan strategi instruksional dan menerima tanggung jawab untuk memfasilitasi pencapaian mereka,memberikan suasana tertib dan memastikannya iklim sekolah kondusif untuk pembelajaran, sering mengevaluasi kemajuan siswa dalam hal ekspektasi kinerja, mengoordinasikan program instruksional secara konsisten dengan tujuan program dan sekolah secara keseluruhan, dan mendukung guru dalam hal pengembangan staf. ${ }^{18}$ Dari paparan latar belakang tersebut sangatlah menarik untuk dikaji bagaimana tugas manajemen puncak dalam pendidikan Islam? Sehingga judul penelitian ini adalah, "Karakteristik Tugas Manajemen Puncak di dalam Pendidikan Islam".

\section{Pembahasan}

\section{Tugas-Tugas Manajemen Puncak dalam Pendidikan Islam}

Wakil kepala sekolah SMP Muhammadiyah 4 Balong Ponorogo sebagai manajemen puncak yang membantu tugas kepemimpinan kepala sekolah memiliki tugas sebagai berikut:

1. Wakil Kepala Sekolah di Bidang Kurikulum

Wakil kepala sekolah di bidang kurikulum di SMP Muhammadiyah 4 Balong Ponorogo, memiliki tugas sebagai berikut: a.) Mengatur program pengajaran, yang meliputi penyusunan program pengajaran, menjabarkan kalender pendidikan, menyusun pembagian tugas mengajar, dan menyusun jadwal KBM. b) Menyusun pengelolaan evaluasi, yang meliputi pembuatan kisi-kisi dan kartu soal, pengadaan soal, pelaksanaan evaluasi belajar, analisis hasil evaluasi, dan menampung hasil murni evaluasi. c). Menyusun pelaksanaan program perbaikan dan pengayaan. d) Pengembangan kurikulum yang meliputi pembentukan rumpun mata pelajaran, mengadakan kegiatan MGMP, membina dan memeriksa administrasi wali kelas, guru, perpustakaan, administrasi laboratorium dan administrasi guru piket, menyusun kriteria dan persyaratan naik/tidak naik ke kelas, lulus/tidak lulus, mengatur pembagian laporan hasil belajar (raport), menyusun peringkat kelas/pararel setiap ulangan umum, meningkatkan stabilitas dan mutu pendidikan, menyusun personalia wali kelas dan petugas guru piket, menyusun program penjurusan siswa bersama BP dan wali kelas, memeriksa dan mengusulkan calon guru teladan kepada kepala madrasah, mengkoordinir dan membina lomba-lomba bidang akdemis di kalangan guru, membantu kepaia madrasah melaksanakan supervisi

\footnotetext{
${ }^{18}$ Shakeshaft, "The Female World of Love.Pdf."
} 
kelas, membina dan memeriksa penyusunan Satuan Pembelajaran, daya serap siswa, deposit soal, program remedial dan pengayaan setiap guru, Dan membuat laporan pelaksanaan tugas kepada madrasah. Dari hasil dokumen job description tersebut dapat diketahui bahwa Wakasek kurikulum memiliki tugas sebagai eksekutif manajer. ${ }^{19}$ Di mana sebagai manajer bertugas untuk menetapkan strategi instruksional dan menerima tanggung jawab untuk memfasilitasi pencapaian mereka,memberikan suasana tertib dan memastikannya iklim sekolah kondusif untuk pembelajaran, sering mengevaluasi kemajuan siswa dalam hal ekspektasi kinerja, mengoordinasikan program instruksional secara konsisten dengan tujuan program dan sekolah secara keseluruhan, dan mendukung guru dalam hal pengembangan staf. ${ }^{20}$

2. Wakil Kepala Sekolah Bidang Keislaman dan Kemuhammadiyahan

Wakil kepala sekolah bidang ini memiliki tugas sebagai berikut: melakukan pengajaran Al-Qur'an dengan metode umi, melakukan MOU dengan lembaga umi foundation, mengadakan sertifikasi pembelajaran Al-Qur'an sesuai dengan metode umi, melakukan koordinasi dengan komite sekolah, dan orang tua siswa, melakukan sosialisasi, membagi masing-masing kelas pembelajaran umi, menjadwalkan kegiatan sholat dhuha berjama'ah, maupun sholat dhuhur berjama'ah, menyusun kegiatan pembiasaan ke-Islaman di dalam kegiatan sekolah sehari-hari. ${ }^{21}$ Dari hasil wawancara tersebut dapat diketahui bahwa Waksek bidang Ismuba memiliki tugas sebagai edukator, dan administrator. Di mana sebagai edukator diharapkan mampu menerapkan sebuah ide, dan gagasan yang tepat untuk membangun budaya profesional di lingkungan sekolah. Mereka juga diharapkan untuk mampu menciptakan sebuah suasana sekolah yang kondusif, serta memberikan bantuan dan arahan terhadap seluruh warga sekolah, juga terus memberikan motivasi terhadap para karyawan di sekolah, dan terampil di dalam melakukan kegiatan pembelajaran yang inovatif seperti team teaching, moving class, dan menyelenggarakan program percepatan bagi siswa-siswi yang memiliki kemampuan lebih. ${ }^{22}$ Sedangkan sebagai administrator tugasnya Tugas administrasi meliputi: menjaga rekam jejak, pengembangan dan pengendalian anggaran, personel, disiplin, penjadwalan, administrasi gedung, perlengkapan dan peralatan, memeriksa akun murid, dan memantau proses instruksional. Diantara tanggung jawab dalam pendidikan area kepemimpinan adalah: motivasi staf, akuntabilitas,

${ }^{19}$ Hasil dokumen job description sekolah.

${ }^{20}$ Shakeshaft, "The Female World of Love.Pdf."

${ }^{21}$ Hasil wawancara dengan Muslimin, M. Pd selaku wakil kepala sekolah bidang Ismuba, di SMP Muhammadiyah 4 Balong,

${ }^{22}$ Mulyasa, Manajemen \& Kepemimpinan Kepala Sekolah (Jakarta: Bumi Aksara, 2013). 
peningkatan program, evaluasi dan pengembangan staf,evaluasi kinerja siswa. ${ }^{23}$

3. Wakil Kepala Sekolah Bidang Kesiswaan

Wakil kepala sekolah di bidang ini memiliki tugas sebagai berikut: a). Program Siswa Baru; menyusun program PSB dan pelaksanaannya, menyimpan file siswa baru, mengklasifikasi data orientasi siswa baru, melaksanakan proses penjurusan, melaksanakan masa orientasi siswa baru, pembenahan penetapan kelas siswa baru, Menyusun laporan PSB. b) Program siswa lama; membuat berita acara hasil sidang kenaikan kelas berikut rangking prestasinya, melakukan pembenahan kelas sesuai dengan rasio yang ditentukan, melakukan proses penjurusan sampai penetapan jurusan khusus sepuluh dengan ditertibkan SK kepala tentang penetapan jurusan, pengaturan mutasi siswa dengan persetujuan kepala, membimbing, mengarahkan dan mengendalikan proses pemilihan pengurus OSIS, mengkoordinir, membina dan mengawasi kegiatan upacara bendera, menyusun Program/Kegiatan Kesiswaan/OSIS. c) Tata tertib siswa; menyusun dan menetapkan tata tertib siswa melalui rapat dewan guru, memasyarakatkan tata tertib untuk semua dewan guru dan para siswa, pengendalian pelaksanaan tata tertib siswa, menciptakan ketahanan siswa madrasah dari gangguan luar yang akan menggoyahkan atau mengganggu citra nama baik sekolah. d) Program ekstra kurikuler; mengoptimalkan fungsi dan tugas dengan mengintensifkan para pembina, menyelenggarakan Latihan Kepemimpinan Dasar Sekolah(LKDS), menyusun program pelaksanaan pekan dakwah, menetapkan kegiatan ekstra kurikuler lainnya sesuai dengan potensi pengembangan hobi dan bakat siswa, membuat pelaporan kegiatan kepada kepala. ${ }^{24}$ Dari hasil dokumen job description tersebut dapat diketahui bahwa Wakasek bidang kesiswaan memiliki tugas sebagai administrasi. Di mana di dalam melaksanakan tugasnya meliputi; menjaga rekam jejak, pengembangan dan pengendalian anggaran, personel, disiplin, penjadwalan, administrasi gedung, perlengkapan dan peralatan, memeriksa akun murid, dan memantau proses instruksional. Diantara tanggung jawab dalam pendidikan area kepemimpinan adalah: motivasi staf, akuntabilitas, peningkatan program, evaluasi dan pengembangan staf,evaluasi kinerja siswa. ${ }^{25}$

4. Wakil Kepala Sekolah Bidang Sarana Prasarana

${ }^{23}$ William D. Greenfield, "Studies of the Assistant Principalship: Toward New a Venues of Inquiry," Education and Urban Society 18, no. 1 (1985): 7-27, https://doi.org/10.1177/0013124585018001002.

${ }^{24}$ Hasil dokumentasi job description.

${ }^{25}$ William D. Greenfield, "Studies of the Assistant Principalship: Toward New a Venues of Inquiry," Education and Urban Society 18, no. 1 (1985): 7-27, https://doi.org/10.1177/0013124585018001002. 
Wakasek bidang sarana dan prasaranan memiliki tugaas sebagai berikut: menyusun program pengadaan, pemeliharaan dan pengamanan barang inventaris khususnya yang berkaitan dengan KBM, mendayagunakan sarana prasarana KBM (termasuk kartu-kartu pelaksanaan pendidikan), menjaga stabilitas kesejahteraan guru dan karyawan, merencanakan kegiatan pendayagunaan sarana dan prasarana sekolah secara optimal, merencanaka, kegiatan teknik pemeliharaan sarana prasarana sekolah, melaksanakan tugas temporer kepala sekolah, mencatat dan menginventariskan tropy/piala/piagam yang diperoleh sekolah atau siswa, memelihara fasilitas sekolah, menyusun laporan bulanan pelaksanaan tugas. ${ }^{26}$ Dari hasil dokumen job description tersebut dapat diketahui bahwa Wakasek sarana dan prasarana memiliki tugas sebagai eksekutif manajer. ${ }^{27}$ Di mana sebagai manajer bertugas untuk menetapkan strategi instruksional dan menerima tanggung jawab untuk memfasilitasi pencapaian mereka,memberikan suasana tertib dan memastikannya iklim sekolah kondusif untuk pembelajaran, sering mengevaluasi kemajuan siswa dalam hal ekspektasi kinerja, mengoordinasikan program instruksional secara konsisten dengan tujuan program dan sekolah secara keseluruhan, dan mendukung guru dalam hal pengembangan staf. ${ }^{28}$

\section{Kesimpulan}

Tugas manajemen puncak dalam pendidikan Islam di SMP Muhammadiyah 4 Balong Ponorogo, telah dilakukan oleh masing-masing Waksek yang meliputi; 1. Wakasek kurikulum. 2. Wakasek Ismuba. 3. Wakasek Kesiswaan. 4. Wakasek Sarana dan Prasarana. Di mana masingmasing wakask tersebut memiliki karakteristik tugas masing-masing yaitu: 1 . Wakasek kurikulum di dalam menjalankan tugasnya karakteristik yang dimilikinya sebagai eksekutif manajer. 2. Wakasek Ismuba di dalam menjalankan tugasnya karakteristik yang dimilikinya sebagai edukator, dan administrator. 3. Wakasek kesiswaan di dalam menjalankan tugasnya memiliki karakteristik sebagai administrasi. 4. Wakasek sarana dan prasarana di dalam menjalankan tugasnya memiliki karateristik sebagai eksekutif manajer.

${ }^{26}{ }^{26}$ Hasil dokumentasi job description.

${ }^{27}$ Hasil dokumen job description sekolah.

${ }^{28}$ Shakeshaft, "The Female World of Love.Pdf." 


\section{Daftar Pustaka}

Ake. “Top Management Education, An Evaluation Study.Swedish Council for Personnel Administration, Stockholm.," 1967.

Alam, Lukis. "Internalisasi Pendidikan Islam Dalam Perguruan Tinggi Di Kampus." Istawa: Jurnal Pendidikan Islam 1, no. 2 (2016): 101. https://doi.org/10.24269/ijpi.vii2.171.

Ali Khalid Mardawi. “Islamic Educatin Toward a Comprehensive View." King Saud University 1, no. 2 (1989): 3-14.

Anwar, Choirul. "Empathy Based Allocation As The Role In Controlling Sustainability Operation ( A Phenomenological Study At Pondok Pesantren Tebuireng )." Review of Integrative Business $\mathcal{E}$ Economics Research 5, no. 1 (2016): 267-95. http://buscompress.com/journalhome.html.

Bafadhol, Ibrahim. "Lembaga Pendidikan Islam Di Indoesia." Jurnal Edukasi Islami Jurnal Pendidikan Islam o6, no. 11 (2017): 72.

Dadang Suhardan. Supervisi Professional Dalam Meningkatkan Mutu Pembelajaran Di Era Otonomi Daerah. Bandung. Alfabeta, 2010.

Deem, Rosemary, and Kevin J. Brehony. "Management as Ideology: The Case of 'new Managerialism' in Higher Education." Oxford Review of Education 31, no. 2 (June 2005): 217-35. https://doi.org/10.1080/03054980500117827.

Donni Juni Priansa, Rismi Somad. Manajemen Supervisi Dan Kepemimpinan Kepala Sekolah. Bandung: Alfabeta, 2014.

Greenfield, William D. "Studies of the Assistant Principalship: Toward New a Venues of Inquiry." Education and Urban Society 18, no. 1 (1985): 7-27. https://doi.org/10.1177/0013124585018001002.

Imron Mutaqin. "Supervision Planning at Islamic Education Institutions: Google Scholar Library Studies and Mendeley's Reference Manager." Istawa: Jurnal Pendidikan Islam 5, no. 02 (2020): 222-38.

Kusuma Pertiwi, Adhe, Sinta Septia Anggra Cahyani, Risma Chulashotud Diana, and Imam Gunawan. "The Leadership of Kyai: A Descriptive Study." In Atlantis-Press.Com, 2018. https://doi.org/10.2991/coema- 
18.2018.32.

Ma'ruf, Muhammad. “Kepemimpinan Kepala Sekolah Dalam Meningkatkan Kualitas Pendidikan Di SMP Islam Darul Karomah Mandaranrejo Pasuruan.” Journal EVALUASI 1, no. $1 \quad$ (2018): 42. https://doi.org/10.32478/evaluasi.vii1.64.

Manan, Syaepul. "Pembinaan Akhlak Mulia Melalui Keteladanan Dan Pembiasaan.” Jurnal Pendidikan Agama Islam -Ta'lim 15, no. 2 (2017): 4965.

Mappasiara. "PENDIDIKAN ISLAM (Pengertian, Ruang Lingkup Dan Epistemologinya).” Rumah Jurnal UIN Alaudin Makassar VII, no. 1 (2018): 147-6o.

Marno, Triyo Supriyanto. Manajemen Dan Kepemimpinan Pendidikan Islam. Bandung: Refika Aditama, 2013.

Menteri Pendidikan dan Kebudayaan RI. "Peraturan Menteri Pendidikan Dan Kebudayaan Nomor 34 Tahun 2018.” Bsnp, no. 1 (2018): 43. https://doi.org/10.1017/CBO9781107415324.004.

Mulyasa. Manajemen E Kepemimpinan Kepala Sekolah. Jakarta: Bumi Aksara, 2013.

N.Hall. In 7th International Confferences on Bussines Management Education. Unpub Mimeogr: OECD, 1960.

Pardaniı, Kadek Kusuma, and I Gst Ayu Eka Damayanthi. "Pengaruh Pemanfaatan Teknologi, Partisipasi Pemakai, Manajemen Puncak, Dan Kemampuan Pemakai Terhadap Efektivitas Sistem Informasi Akuntansi." E-Jurnal Akuntansi 19, no. 03 (2017): 2234-61.

Pendidikan, Dosen, Agama Islam, Ftk Iain Raden, and Intan Lampung. “Tujuan Pendidikan Islam.” Jurnal Pendidikan Islam 6, no. November (2015): $151-66$.

http://103.88.229.8/index.php/tadzkiyyah/article/view/1876.

Rohman, Miftahur, and Hairudin Hairudin. "Konsep Tujuan Pendidikan Islam Perspektif Nilai-Nilai Sosial-Kultural.” Al-Tadzkiyyah: Jurnal Pendidikan Islam 9, no. 1 (2018): 21. https://doi.org/10.24042/atjpi.v9i1.2603.

Salleh, MS. "Strategizing Islamic Education." ijern.com, 2013. 
www.uscwm.org/.

Shakeshaft, C. "The Female World of Love.Pdf." Education Digest, 1986. https://scholar.google.com/scholar?hl=en\&as_sdt=0\%2C $5 \& q=S h a k e s h a f t$ $\% 2 \mathrm{C}+\mathrm{C} .+\% 281986 \% 29$. + The+female+world+of +school+administrators.+E ducation+Digest $\% 2 \mathrm{C}+52+\% 281 \% 29 \% 2 \mathrm{C}+30-31 . \& \mathrm{btnG}=$.

Shobaki, Mazen J Al, Youssef M Abu Amuna, and Samy S Abu Naser. "The Impact of Top Management Support for Strategic Planning on Crisis Management: Case Study on UNRWA-Gaza Strip." International Journal of Academic Research and Development, 2016, 2455-4197. www.academicsjournal.com.

Slamet Untung IAIN Pekalongan, Moh. "IMPLEMENTING FUNCTIONS OF MANAGEMENT IN ISLAMIC EDUCATION INSTITUTIONS,” n.d.

Solihin. Pengantar Manajemen. Jakarta: Erlangga, 2009.

Sudarsana, Ketut, Ni Kadek, Vivin Mahayuni, Janner Simarmata, I Made, Dwi Susila, Adnyana Putu, et al. PENGEMBANGAN MEDIA PEMBELAJARAN BERBASIS TEKNOLOGI PENDIDIKAN. Jayapanguspress.Penerbit.Org. Accessed July 9, 2020. http://jayapanguspress.org.

Sulistia Paudi, Ikhfan, Arifin Suking. "Kinerja Wakil Kepala Sekolah Menengah Pertama Dilihat Dari Tugas Pokok Dan Fungsiny." Manajemen Pendidikan 02, no. 02 (2020): 192-205.

Tanujaya, Benidiktus, Jeinne Mumu, and Gaguk Margono. "The Relationship between Higher Order Thinking Skills and Academic Performance of Student in Mathematics Instruction." International Education Studies 10, no. 11 (2017): 78. https://doi.org/10.5539/ies.v1on11p78.

Taylor, John; Miroiu, Adria. Policy-Making, Strategic Planning, and Management of HigherEducation. Papers on Higher Educati, 2002. https://files.eric.ed.gov/fulltext/ED475531.pdf.

Thoyib, Muhammad. Model Otonomi Manajemen Mutu Perguruan Tinggi Islam Di Indonesia. Yogyakarta: Cetta Media, 2015.

Usman, Husaini. Manajemen Teori, Praktik, Dan Riset Pendidikan. Jakarta: Bumi Aksara, 2014.

Warner, Jerold B, Ross L. Watts, and Karen H Wruck. "Stock Prices and Top 
Management Changes." Journal of Financial Economics 20, no. C (1988): 461-92. https://doi.org/10.1016/0304-405X(88)90054-2.

Wheelen, T. L., Hunger, J. D., Hoffman, A. N., \& Bamford, C. Strategic Management and Business Policy: Globalization, Innovation and Sustainablility 14th Edition. Pearson, 2014. 